\title{
Evaluation of Front Line Demonstration on Drought Tolerant Rice (Oryza sativa L.) Variety Satyabhama in Mid Central Table Land Zone of Odisha
}

\author{
Tiryak Kumar Samant*
}

Krishi Vigyan Kendra (OUAT), Angul, Odisha (759 132), India

\section{Corresponding Author}

Tiryak Kumar Samant

e-mail: tksamant_2003@yahoo.co.in
Article History

Article ID: AR1846b

Received in $17^{\text {th }}$ September, 2017

Received in revised form 19 ${ }^{\text {th }}$ October, 2017

Accepted in final form $29^{\text {th }}$ November, 2017

\begin{abstract}
The study was carried out through front line demonstrations during kharif season of 2015 and 2016 in mid central table land zone of Odisha with an objective to evaluate the performances of improved practice of drought tolerant high yielding variety (HYV) rice Satyabhama as compared to the local check (Khandagiri). Satyabhama matured at 110 days, recorded higher plant height (103.76 cm), effective tillers plant ${ }^{-1}$ (12.44), length of panicle $(23.2 \mathrm{~cm})$, filled grains panicle ${ }^{-1}(129.72)$, spikelet fertility $(92.29 \%)$ and 1000 grain weight (23.4 g) than Khandagiri. The same also produced grain yield $40.83 \mathrm{q} \mathrm{ha}^{-1}$ which is $40.94 \%$ higher than Khandagiri with harvest index (46.72\%) and production efficiency $\left(37.12 \mathrm{~kg} \mathrm{ha}^{-1}\right.$ day $^{-1}$ ). The HYV rice Satyabhama gave higher gross return ₹ 63493.9 ha $^{-1}$ with a benefit-cost ratio 1.98 , profitability (₹ 85.92 $\mathrm{ha}^{-1}$ day $^{-1}$ ) and additional net return ₹ $13424.15 \mathrm{ha}^{-1}$ as compared to farmers practice and the study showed that horizontal spread of area from 1.0 ha during 2015 to 25 ha during 2016 under improved technology with technological gap, extension gap and technology index; $19.17 \mathrm{q} \mathrm{ha}^{-1}, 11.86 \mathrm{q} \mathrm{ha}^{-1}, 31.95 \%$ respectively. The growth and yield performance of Satyabhama was found to be satisfactory in spite of occurrence of frequent dry spells during different crop growth stages. Thus the existing variety Khandagiri may be replaced by Satyabhama for higher productivity, income and drought tolerant capacity.
\end{abstract}

Keywords: Drought tolerant, Economics, Front line demonstration, rice, Satyabhama, technology gap

\section{Introduction}

Rice is the predominant crop of Odisha with a total coverage of 4.2 mha which is about $65 \%$ of the total cultivable area of the state. Area under rice crop in Angul district of the state is 0.08 mha with a productivity of $19.3 \mathrm{q} \mathrm{ha}^{-1}$ which is $6 \%$ higher than the state (Anonymus 2014). Non adoption of high yielding varieties and improved production technology are key factors for low productivity of rice. In future, there is no scope for further expansion in rice area and to achieve this goal, conventional breeding methods need to be supplemented with the innovative techniques. Achieving self-sufficiency in rice production and maintaining price stability are important political objectives in low-income countries because of the importance of this crop in providing national food security and generating employment and income for low-income people (Ghosh et al., 2009). Indian agriculture is mainly dependent on the climate of India: a favorable southwest summer monsoon is critical in securing water for irrigating Indian crops. In some parts of India, the failure of the monsoon results in water shortage, resulting in below-average crop yield. This is particularly true of major drought-prone regions such as southern and eastern Maharashtra, northern Karnataka,
Andhra Pradesh, Orissa, Gujarat, and Rajasthan (Mall et al., 2017). Among the effects of impending climate change, drought will have a profound impact on crop productivity in the future. Response to drought stress has been studied widely, and the model plant Arabidopsis has guided the studies on crop plants with genome sequence information viz., rice, wheat, maize and sorghum. Since the value of functions of genes, dynamics of pathways and interaction of networks for drought tolerance in plants can only be judged by evidence from field performance (Shanker et al., 2014). Developing drought tolerant rice cultivars is considered to be one of the most effective and economic approaches to ensuring food security (Verma and Srivastava, 2004). A large portion about $70 \%$ of area under rice in India is drought prone rainfed, but it has not been exploited to full potential due to lack of suitable drought tolerant or resistant varieties (Kumar et al., 2012). There is hardly any scope to replace the rice crop considering the precipitation of less than $1500 \mathrm{~mm}$ rainfall during the monsoon season. However, multiple cropping system using short duration rice varieties and intensive input management may enhance the land use efficiency and increase the production level if sowing of rabi crops are made 
in time (Khanda et al., 2005). Upland rice cultivars with drought avoidance (through deep root systems) and drought recovery abilities are preferred. Upland rice in India is grown during the wet season (June-Sept). Selecting a suitable variety which matches the rainfall duration will be a major non monetary input in upland cultivation (Singh, 2012).

Adoption gap could be minimized and yield could be enhanced through Front Line Demonstration (FLDs). FLD indicates demonstration of proven technologies which includes improved production technologies, high yielding varieties in farmer's field in different agro ecological situations against the farmer's practices. By conduction of front line demonstrations on farmer's field there was significant increase in knowledge level of the farmers and majority of farmer's showed high level of satisfaction about demonstrated technologies (Raj at el., 2014). A vast gap has been observed between knowledge production and knowledge urtilization. Front line demonstrations on rice including recently released early maturing, high yielding, fine grained, diseased resistant varieties in farmers field may be helpful (Singh et al., 2015).

Keeping in view such problems an attempt was made with an objective to evaluate growth and yield parameters of newly released promising drought tolerant high yielding variety rice $\mathrm{cv}$. Satyabhama through front line demonstration for its suitability in the existing farming situation for substitution old variety ( Khandagiri) with higher productivity and income.

\section{Materials and Methods}

The study was carried out through front line demonstrations on farmers field during kharif season of 2015 and 2016 in Sandhapal village of Angul district in mid central table land zone of Odisha with an objective to evaluate the performances of improved technology of drought tolerant high yielding variety(HYV) rice Satyabhama as compared to the local check (Khandagiri). The study site lies in $84^{\circ} 58^{\prime}$ to $85^{\circ} 21^{\prime} \mathrm{E}$ longitude and $20^{\circ} 58^{\prime}$ to $21^{\circ} 04^{\prime} \mathrm{N}$ latitude and average elevation of 300 $\mathrm{m}$ above $\mathrm{msl}$. The mean maximum and mean minimum temperature registered in the year was $32.3^{\circ} \mathrm{C}$ and $13.4{ }^{\circ} \mathrm{C}$ respectively. Total of 694.8 and $707.4 \mathrm{~mm}$ rainfall received during 2015 and 2016 respectively during the cropping period. The soil of the study area was slightly acidic in reaction $\mathrm{pH}$ 5.3 to 5.7 ), loam in texture with medium organic carbon content $(0.53$ to $0.56 \%)$, medium in nitrogen (277 to $282 \mathrm{~kg}$ $\mathrm{ha}^{-1}$ ), low in phosphorus (9.5 to $11.4 \mathrm{~kg} \mathrm{ha}^{-1}$ ) and medium in potassium (177 to $186 \mathrm{~kg} \mathrm{ha}^{-1}$ ) content(Jackson, 1973). Fifteen different farmers in 6.0 hectare of land cultivated the HYV rice cv. Satyabhama with recommended package of practices. They were supplied with seed and fertilizers. Besides farmers practice of HYV rice cV. Khandagiri was selected as local check. The crops were direct sown during $4^{\text {th }}$ week of June and harvested during $1^{\text {st }}$ week of October. Observations on different growth and yield parameters were taken and economic analysis was done by calculating cost of cultivation, gross return, net return and B: C ratio. Final crop yield (grain
\& straw) were recorded and the gross return were calculated on the basis of minimum support price of the produce. Harvest index is the relationship between economic yield and biological yield (Gardner et al., 1985). It was calculated by using the following formula:

Harvest index $(\%)=\frac{\text { Economic yield }}{\text { Biological yield }} \times 100$

For the introduction of the technology, different extension approaches through regular field visit, farmers training programmes \& interpersonal communication were made. Trainings on farmers and farm women were conducted for the awareness among the farmers and field days were celebrated for the horizontal spread of technology. Also leaflets and pamphlets on improved package of practices of rice cultivation were distributed among the farmers in the village. Further study on technology gap, extension gap and technology index were calculated by the formula as suggested by Samui et al. (2000).

Technology gap=Potential yield-Demonstration yield

Extension gap=Demonstration yield-Farmers yield

Technology index $(\%)=\frac{\text { Technology gap }}{\text { Potential yield }} \times 100$

Profitability of the system was calculated by dividing the net return ha-1 in a sequence by 365 days. The production efficiency value was calculated by dividing the total grain production ha-1 with total duration of crop (Patil et al., 1995). Tabular analysis involving simple statistical tools like mean was done by standard formula to analyze the data and draw conclusions and implications (Gomez and Gomez, 1984).

Details of Technology: The high yielding variety "Satyabhama"(CR Dhan 100) was released from ICARNational Rice Research Institute (NRRI), Cuttack in 2012 as a suitable variety for upland ecosystem. It is a short duration variety having average yield of $47.0 \mathrm{q} \mathrm{ha}^{-1}$, potential yieldof $60.0 \mathrm{q} \mathrm{ha}^{-1}$ and matures in 110 days. It is drought tolerant, non lodging, having early thresh ability and long slender grains. It is moderately tolerant to leaf blast, rice tungo virus, glume discoloration; resistance to leaf folder, stem borer and rice whorl maggot. Keeping all these in view the variety "Satyabhama" has been recommended for cultivation in Odisha.

\section{Results and Discussion}

3.1. Days to maturity, plant height, no of tillers plant ${ }^{-1}$, effective plant $^{-1}$ and effectivity of tiller

The improved practice (Satyabhama) showed 15 days delayed in maturity (110 days) with taller plant height $(103.76 \mathrm{~cm})$, higher no of tillers plant ${ }^{-1}(16.08)$, effective tillers plant ${ }^{-1}$ (12.44), and effectivity of tiller (77.36\%) (Figure 1) as compared to farmers practice (Khandagiri) which was attributed to their genetic variability and varietal difference. The differential 


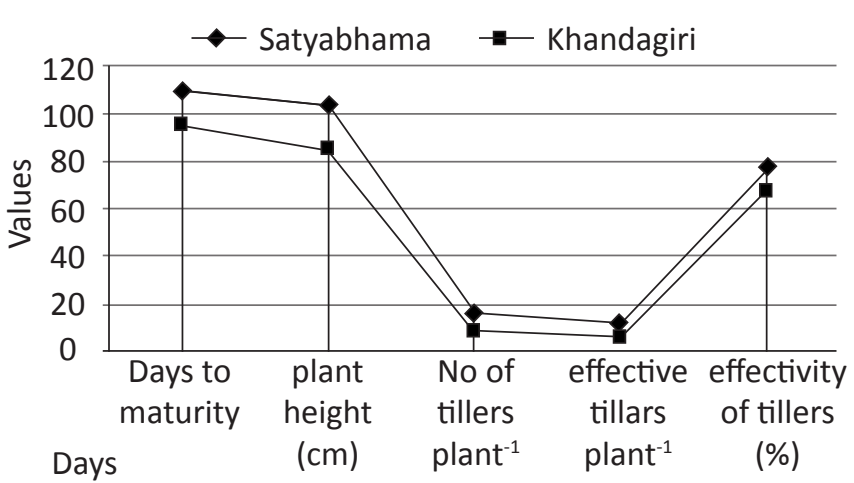

Figure 1: Days to maturity, plant height, no of tillers plant ${ }^{-1}$, effective plant ${ }^{-1}$ and effectivity of tillers under front line demonstration

response of tillering in the genotype could be attributed to its genetic potentiality. These results are in agreement with Sarker at el. (2013).

3.2. Length of panicle, total grains panicle ${ }^{-1}$, filled grains panicle $^{-1}$, spikelet fertility and 1000 grain weight

Analysis of data (Figure 2) indicated that higher length of panicle $(23.2 \mathrm{~cm})$, no of total grains panicle ${ }^{-1}(140.56)$, filled grains panicle $^{-1}$ (129.72), spikelet fertility (92.29\%) and 1000 grain weight $(23.4 \mathrm{~g})$ were produced in Satyabhama than the local check owing to reduced no of unfilled spikelet. This finding was in corroborated with findings of Pandey and Shukla, 2015.



Yield parameters

Figure 2: Length of panicle, total grains panicle ${ }^{-1}$, filled grains panicle $^{-1}$, spikelet fertility and 1000 grain weight under front Line demonstration.
3.3. Grain yield, straw yield, harvest index and production efficiency

Results of front line demonstrations indicated that the improved practice of HYV Satyabhama (Table 1) produced grain yield $40.83 \mathrm{q} \mathrm{ha}^{-1}$ which is $40.94 \%$ higher than Khandagiri. This may be attributed to higher panicle production, larger panicles and high tillering capacity in some cases (C.R.R.I, 2014). The trend of straw yields of two varieties was similar with grain yield. Satyabhama recorded the higher straw yield (46.57 q ha-1) with harvest index (46.72\%) and production efficiency (37.12 $\mathrm{kg} \mathrm{ha}^{-1}$ day $^{-1}$ ) in comparison to Khandagiri attributing to high vegetative biomass production (C.R.R.I, 2013). This might be due to the production of higher number of effective tillers plant ${ }^{-1}$ and number of grains panicle ${ }^{-1}$. These results were in conformity with Tripathi at el. (2013).

\subsection{Tolerance to drought}

Data on Table 2 indicated that during the year 2016, the crop received a total rainfall of $707.4 \mathrm{~mm}$ during its growth period. A total of 12 dry spells were occurred during different crop growth stages. There were long dry spells during seedling, booting and milking stages for a period of 7, 9 and 7 days respectively. Short dry spells also found during tillering, panicle initiation, heading flowering and maturity stages. In spite of occurrence of frequent dry spells during different crop growth stages, the growth and yield performance were satisfactory might be due to its genetic potentiality. During the year 2015, the crop received a total rainfall of $694.8 \mathrm{~mm}$ during its growth period. Long dry spells occurred during seedling, tillering, flowering milking and maturity stage while comparatively short dry spells occurred during rest of growth stages. Still the HYV Satyabhama performs well due to its drought tolerant capacity. The results of this study were in good agreement with the earlier findings in different rice genotypes by Kumar et al. (2013).

\subsection{Technology gap, extension gap and technology index}

Technology gap: The demonstrations in both the year recorded technology gap of 20.5 q ha $^{-1}$ during 2015 which was $14.9 \%$ higher than that during 2016 (Table 3). This may be attributed to the differential soil fertility status and variable climatic conditions (Mandavkar et al., 2012). Technology gap indicated the needs to create awareness among the farmers through various extension means for adoption of HYV Satyabhama for reducing the gap.

Table 1: Effect of front line demonstration on grain yield, straw yield, harvest index and production efficiency

\begin{tabular}{|c|c|c|c|c|c|c|c|c|c|}
\hline \multirow[t]{2}{*}{ Year } & \multicolumn{2}{|c|}{ Yield (q ha-1) } & \multicolumn{2}{|c|}{ Straw (q ha-1) } & \multicolumn{2}{|c|}{ Harvest index (\%) } & \multirow[t]{2}{*}{$\begin{array}{l}\% \text { of increase in grain } \\
\text { yield over local check }\end{array}$} & \multicolumn{2}{|c|}{$\begin{array}{l}\text { Production efficiency } \\
\left(\mathrm{kg} \mathrm{ha}^{-1} \text { day }^{-1}\right)\end{array}$} \\
\hline & IP & FP & IP & FP & IP & FP & & IP & FP \\
\hline 2015 & 39.5 & 28.6 & 45.7 & 37.4 & 46.36 & 43.33 & 38.11 & 35.91 & 30.11 \\
\hline 2016 & 42.16 & 29.34 & 47.43 & 39.39 & 47.06 & 42.69 & 43.69 & 38.33 & 30.88 \\
\hline Mean & 40.83 & 28.97 & 46.57 & 38.40 & 46.72 & 43.0 & 40.94 & 37.12 & 30.49 \\
\hline
\end{tabular}

*IP: Improved practice (Satyabhama); FP: Farmer's practice (Khandagiri) 
Table 2: Effect of front line demonstration on drought tolerance capacity under dry spells during both the year

\begin{tabular}{|c|c|c|c|c|c|c|c|}
\hline \multicolumn{4}{|c|}{2015} & \multicolumn{4}{|c|}{2016} \\
\hline Period of dry spell & $\begin{array}{c}\text { No. of } \\
\text { days }\end{array}$ & Stages of crop & $\begin{array}{l}\text { Total rain- } \\
\text { fall received } \\
(\mathrm{mm})\end{array}$ & $\begin{array}{l}\text { Period of dry } \\
\text { spell }\end{array}$ & $\begin{array}{c}\text { No. of } \\
\text { days }\end{array}$ & Stages of crop & $\begin{array}{l}\text { Total rainfall } \\
\text { received } \\
(\mathrm{mm})\end{array}$ \\
\hline 24-29 June & 6 & Seedling & 694.8 & 21-27 June & 7 & Seedling & 707.4 \\
\hline 1-4 July & 4 & Seedling & & 12-13 July & 2 & Tillering & \\
\hline 12-15 July & 4 & Tillering & & 20-22 July & 3 & Tillering & \\
\hline 17-23 July & 7 & Tillering & & 28-30 July & 3 & Tillering & \\
\hline 29-30 July & 2 & Tillering & & 8-9 August & 2 & Tillering & \\
\hline 6-9 August & 4 & Tillering & & 13-15 August & 3 & Panicle initiation & \\
\hline 18-19 August & 2 & Panicle initiation & & 17-25 August & 9 & Booting & \\
\hline 21-24 August & 4 & Booting & & 27-31 August & 5 & Heading & \\
\hline 1-3 Sept & 3 & Heading & & 8-10 Sept & 3 & Heading & \\
\hline 7-12 Sept & 6 & Flowering & & 12-15 Sept & 4 & Flowering & \\
\hline 21-30 Sept & 9 & Milking & & 17-23 Sept & 7 & Milking & \\
\hline 1-11 October & 11 & Maturity & & 2-6 October & 4 & Maturity & \\
\hline
\end{tabular}

"Source: District Agriculture Office, Angul, Odisha

Table 3: Effect of front line demonstration on technology gap, extension gap and technology index

\begin{tabular}{|c|c|c|c|c|c|c|c|c|}
\hline \multirow[t]{2}{*}{ Year } & \multirow{2}{*}{$\begin{array}{l}\text { Area } \\
\text { (ha) }\end{array}$} & \multirow{2}{*}{$\begin{array}{c}\text { No of } \\
\text { farmers }\end{array}$} & \multicolumn{3}{|c|}{ Yield (q ha-1) } & \multirow{2}{*}{$\begin{array}{l}\text { Technology } \\
\text { gap (q ha-1) }\end{array}$} & \multirow{2}{*}{$\begin{array}{l}\text { Extension } \\
\text { gap }\left(\mathrm{q} \mathrm{ha} \mathrm{h}^{-1}\right)\end{array}$} & \multirow{2}{*}{$\begin{array}{c}\text { Technology } \\
\text { index (\%) }\end{array}$} \\
\hline & & & $\begin{array}{l}\text { Potential } \\
\text { yield }\end{array}$ & $\begin{array}{l}\text { Improved } \\
\text { practice }\end{array}$ & Local check & & & \\
\hline 2015 & 1.0 & 5 & 60.0 & 39.5 & 28.6 & 20.5 & 10.9 & 34.17 \\
\hline 2016 & 5.0 & 10 & 60.0 & 42.16 & 29.34 & 17.84 & 12.82 & 29.73 \\
\hline Mean & 6.0 & 15 & 60.0 & 40.83 & 28.97 & 19.17 & 11.86 & 31.95 \\
\hline
\end{tabular}

Extension gap: Higher extension gap (12.82 q ha-1) was found during 2016 and lower (10.9 $\mathrm{q} \mathrm{ha}^{-1}$ ) was in 2016 (Table 3) which may be due to higher yield of rice variety in demonstration plots. More and more use of latest production technologies with high yielding variety will subsequently change this alarming trend of galloping extension gap. The new improved technologies will eventually lead to the farmers to discontinue the old varieties and to adopt new variety. Similar results were reported by Sharma et al. (2011).

Technology index: The Technology index was reduced from 34.17 to $29.73 \%$ during 2015 to 2016 (Table 3) which showed the higher feasibility of the demonstrated technology of HYV Satyabhama in farmers field. This finding was in corroboration with the findings of Sujathamma et al. (2015).

\subsection{Technology transferred}

For varietal introduction, different extension approaches were made. The variety Satyabhama could successfully out yield the old variety and recorded eye catching higher yield in uplands. The area under Satyabhama expanded horizontally to 25 ha during kharif, 2016 (Table 4) from a mere one hectare
Table 4: Effect of front line demonstration on transfer of technology

\begin{tabular}{lccc}
\hline Year & \multicolumn{3}{c}{ Horizontal spread of technology } \\
\cline { 2 - 4 } & $\begin{array}{c}\text { No of villages } \\
\text { adopted }\end{array}$ & $\begin{array}{c}\text { No of farmers } \\
\text { adopted }\end{array}$ & Area (ha) \\
\hline $2016-17$ & 40 & 150 & 25 \\
\hline
\end{tabular}

demonstration during first year (2015) of introduction and adopted by 150 farmers in 40 villages. Due to efforts of KVK, scientists field visit, interpersonal communication and individual efforts of the farmers, the variety Satyabhama could spread in the district. Thus the FLD might have a positive impact on farming community in the district over local check. Similar results were also reported by Mondal et al. (2005) in rice crops. Front line demonstration also produced significant positive results and provided the extension functionaries an opportunity to demonstrate the productivity potential and profitability of rice variety and latest production technology under actual farming situations. FLD programmes are very effective in changing attitude, skill and knowledge of improved 
package of practices of high yielding varieties of rice (Singh et al., 2015).

\subsection{Economics}

An analysis on economics (Table 5) revealed that Satyabhama recorded higher gross return ₹ $63493.9 \mathrm{ha}^{-1}$ with a benefitcost ratio 1.98 and additional net return ₹ $13424.15 \mathrm{ha}^{-1}$ as compared to farmers practice. The improved practice also recorded higher profitability ( $₹ 85.92$ ha $^{-1}$ day $^{-1}$ ) than local practice. Mitra et al., 2014 also reported the advantages of growing newly introduced variety over the traditional with higher return, the variation in net return and benefit-cost ratio may be attributed to the variation in the price of agri inputs and produce. These finding are also similar with the findings of Nirmala et al. (2012).

\subsection{Reason of low yield of rice at farmer's field}

\begin{tabular}{|c|c|c|c|c|c|c|c|c|c|c|}
\hline \multirow[t]{2}{*}{ Year } & \multicolumn{5}{|c|}{ Improved practice (Satyabhama) } & \multicolumn{5}{|c|}{ Farmer's practice (Khandagiri) } \\
\hline & $\begin{array}{l}\text { Cost of } \\
\text { cultivation } \\
(₹ \text { ha-1) }\end{array}$ & $\begin{array}{l}\text { Gross } \\
\text { return } \\
\left(₹ \text { ha }^{-1}\right)\end{array}$ & $\begin{array}{c}\text { Net } \\
\text { return } \\
\left(₹ h^{-1}\right)\end{array}$ & $\begin{array}{l}B: C \\
\text { ratio }\end{array}$ & $\begin{array}{l}\text { Profitability } \\
\left(\text { (₹ ha }^{-1} \text { day }^{-1}\right)\end{array}$ & $\begin{array}{l}\text { Cost of } \\
\text { cultivation } \\
\left(₹ \text { ha }^{-1}\right)\end{array}$ & $\begin{array}{l}\text { Gross } \\
\text { return } \\
\left(₹ \text { ha }^{-1}\right)\end{array}$ & $\begin{array}{l}\text { Net } \\
\text { return } \\
\left(₹ \text { ha-1) }^{-1}\right.\end{array}$ & $\begin{array}{l}\mathrm{B}: \mathrm{C} \\
\text { ratio }\end{array}$ & $\begin{array}{l}\text { Profitability } \\
\left(₹ \text { ha }^{-1} \text { day }^{-1}\right)\end{array}$ \\
\hline 2015 & 31430 & 60265 & 28835 & 1.92 & 79.0 & 30245 & 44066 & 13821 & 1.46 & 37.87 \\
\hline 2016 & 32835 & 66722.79 & 33887.79 & 2.03 & 92.84 & 32310 & 54363.50 & 22053.50 & 1.68 & 60.42 \\
\hline Mean & 32132.5 & 63493.9 & 31361.4 & 1.98 & 85.92 & 31277.5 & 49214.75 & 17937.25 & 1.57 & 49.14 \\
\hline
\end{tabular}

*Sale price of paddy seed ₹ $1410 q^{-1}$ \& ₹ $1470 q^{-1}$ for the year 2015 and 2016 respectively and paddy straw ₹ $100 q^{-1}$ for both the year

Delay sowing due to irregular onset of monsoon and non availability of quality seed of suitable variety cause yield reduction in rice. Injudicious application of fertilizers, hand weeding and improper crop geometry by the farmers also cause the lower yield in rice. Inadequate technology transfer to the farmers and insufficient extension services for transfer of technology are some of the factors for low yield of rice in farmer's field. Small and marginal farmers are resource poor having less risk bearing ability and do not dare to invest in the costly input which is aobstacle in adoption of proven technology.

\subsection{Farmers feedback}

The HYV Satyabhama produced higher yield with more tillering capacity and resistance to drought. Overall, the performance of FLD results suggested that it has the potential for increase knowledge of the farmer as well as showed high level at satisfaction about technology.

\section{Conclusion}

Thus, existing HYV of rice Khandagiri may be replaced with HYV Satyabhama because of higher productivity, income and drought tolerant capacity. HYV Satyabhama was found to be suitable since it fits well to the existing farming situation and also it had been appreciated by the farmers.

\section{Acknowledgement}

The author is thankful to the Director, ICAR-Agriculture Technology Application Research Institute (ATARI), Zone-VII, Jabalpur and Director, ICAR-National Rice Research Institute, Cuttack, Odisha for providing the logistics and funding to carry out the study.

\section{References}

Anonymous, 2014. Odisha Agriculture Statistics 2013-14. Directorate of Agriculture and Food Production. Govt of Odisha, 46.

CRRI, 2013. Krishi Vigyan Kendras: Front line demonstration. C.R.R.I. Annual Report 2012-13, 111.

CRRI, 2014., Biochemistry and Physiology of Rice in Relation to Grain and Nutritional Quality, Photosynthetic Efficiency and Abiotic Stress Tolerance. C.R.R.I. Annual Report 2012-13, 113.

Gardner, F.P., Pearce, R.B., Mistecell, R.I., 1985. Physiology of Crop Plants. lowa State University.Press, lowa.pp.66

Ghosh, R.K., Sharma, L., Barman, S., Dolai, A.K., 2009. System of rice Intensification: The alternate approach for increasing production of field crops. Journal of Crop and Weed (5), 63-67.

Gomez, K.A., Gomez, A.A., 1984. Statistical procedures for agricultural research. John wiley and Sons, New York.

Jackson, M.L., 1973. Soil Chemical analysis. Prentice Hall of India Private Limited, New Delhi.

Khanda, C.M., Mandal, B.K., Garnayak, L.M., 2005. Effect of nutrient management on nutrient uptake and yield of component crops in rice-based cropping systems. Indian Journal of Agronomy 50, 1-5.

Kumar, S., Singh, P.K., Verma, G.P., Singh, K., Chaudhary, R.K., Kumar, M., 2012. Interrelationships for yield and component traits in rainfed upland rice. Oryza 49(1), 57-59.

Kumar, S., Elanchezhian, R., Singh, S.S., Kumar, C., Pradhan, S.K., Mali, A.K., Singh, O.N., Kumar, A., 2013. Yield response of rice genotypes to reproductive stage drought adapted to drought prone rainfed lowland. 
Oryza 50(4), 344-350.

Mandavkar, P.M., Sawant, P.A. , Mahadik., 2012. Evaluation of Front line demonstration trial on rice in Raigad district of Maharastra. Rajstan Journal of Extension Education 20, 4-6.

Mitra, B., Mukherjee, S., Biswas, S., 2014. Promotion of short duration rice variety Gotra Bidhan-1(IET 17430) through front line demonstrations in terai region of West Bengal. Journal of Crop and Weed 10(1), 111-114.

Mall, A.K., Swain, P., Singh, O.N., 2017. Identifying Drought Tolerant Genotypes of Rice (Oryza sativa L.) Using Participatory Research Approach for Resource Poor Farmers of Orissa. International Journal of Current Microbiology and Applied Sciences 6(7), 182-188.

Mondal, M.M.A., Islam, A.F.M.S., Siddique, M.A., 2005. Performance of 11 modern Transplant aman cultivar in the northern region of Bangladesh. Bangladesh Journal of Crop Science 16, 23-29.

Nirmala, B., Vasudev, N., Suhasini, K., 2012. A comparison of economic potential of HYVs Hybrid rice cultivation in Ambedkarnagar district of Uttar pradesh. World Journal of Agronomy 1(1), 07-10.

Pandey, V., Shukla, A., 2015. Acclimation and tolerance strategies of Rice under drought stress. Rice Science 22(4), 147-161.

Patil, E.N., Jowale, S., Mahayan, M.S., 1995. Production potential, economics and fertility status of soil as influenced by wheat-based cropping system Indian Journal of Agronomy 40(4), 544-548.

Raj, A.D., Yadav, V., Rathod, J.H., 2014. Evaluation of Front Line Demonstration on yield of Pigeonpea(Cajanus Cajan L.)in Tribal Region of Gujarat. Research Journal of Agricultural Sciences 5(1), 94-96.
Samui, S.K., Maitra, S., Roy, D.K., Mondal, A.K., Saha, D., 2000. Evaluation on front line demonstration on groundnut (Arachis hypogea L.). Journal of Indian Society Coastal Agricultural Research 18, 180-183.

Sarker, C.B., Zahan, M., Majumdar, U.K., Islam, M.A., Roy, B., 2013. Growth and yield potential of some local and high yielding boro rice cultivars Journal of agroforestry and environment 7(1), 107-110.

Shanker, A.K., Maheswari, M., Yadav, S.K., Desai, S., Bhanu, D., Attal, N.B., Venkateswarlu, B., 2014. Drought stress responses in crops. Functional and Integrative Genomics 14(1), 11-12.

Sharma, P., Khar, S., Kumar, S., Ishar, A., Prakash, S., Mahajan, V., Jamwal, S., 2011. Economic impact of front line demonstrations on cereals in Poonch district of Jammu and Kashmir. Journal of Progressive Agriculture 2, 21-25.

Singh, M.K., 2012. Weed management in upland rice. Oryza 49(1), 1-9.

Singh, T., Pun, K.B. Satapathy, B.S., Saikia, K., Lenka, S., 2015. Incremental yield and returns from rice variety Naveen in front line demonstrations-an analysis. Oryza 52(1), 59-64.

Sujathamma, P., Reddy, K.D., Usharani, G., 2015. Yield gap analysis if rice for technological intervention. The Ecoscan 9( 1\&2), 235-237.

Tripathi, K., Pandey, J., Saxsena, A., 2013. Performance of local , improved and hybrid rice varieties in district Rewa, (M.P), India. International Journal of Pharmacy \&life Science 4(12), 3205-3208.

Verma, O.P., Srivastava, H.K., 2004. Productive association of quantitative traits in diverse ecotypes of rice (Oryza sativa L). Journal of Sustainable Agriculture (USA) 25(2), 75-91. 